\title{
Physical and Chemical Methods Used for Determination of Structures of Some Imines Derived from Different Carbonyl Compounds
}

\author{
A.S.P.Azzouz and D.B.T.Bakzo \\ Chemistry Department, College of Education, University of Mosul

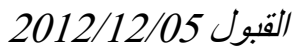 \\ تاريخ الاستلام 2012/08/13
}

\section{Abstract}

The project is concerned with the preparation of fifteen imines derived from 2 -acetyl pyridine , 3 or 4 -hydroxy benzaldehyde and m-anisaldehyde with aromatic primary amines by standard method .

These imines include namely ,hydroxylamine hydrochloride,o,m,p-amino phenols ,4-amino naphthol ,bromo or chloro aniline and p-anisidine .

The main aims of the study is the determination of structures of these imines by the available physical method ,namely ,the melting points ,boiling points , U.V and IR spectra . Some chemical tests for functional groups are also included .This seems important from chemistry point of view as in the elucidation of tautomerism reactions happen in some oximes and phenolic oximes . Finally, the influence of inter molecular hydrogen bonding on association (polymerization) of imines was also discussed . Key words: Imines ,Structures,U.V-IR spectra, tautomerism and hydrogen bonding.

الخلاصة

يثـــتمل البحث على تحضــير 15 ايمين مشــتقة من 2-اســيتايل بريدين , 3 او 4 -

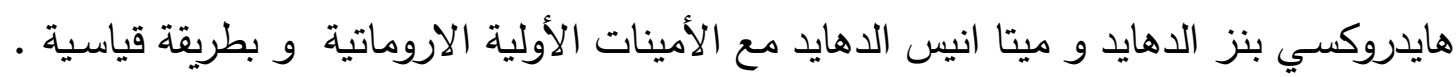

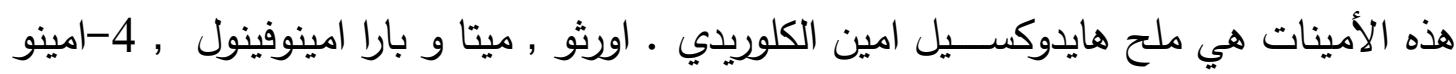

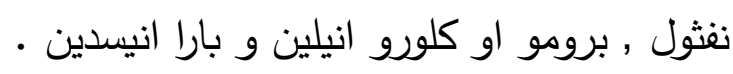

الهدف الرئيسـي من البحث هو تعين الهيئات التركيبية للايمينات بطريقة فيزيائية متوفرة مثل

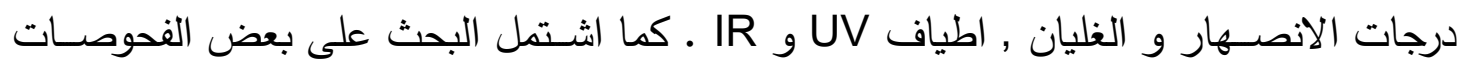

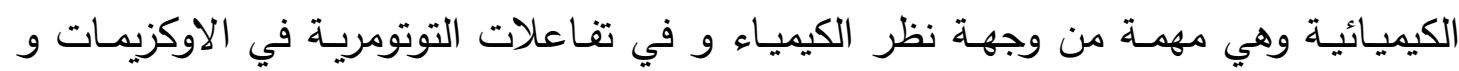

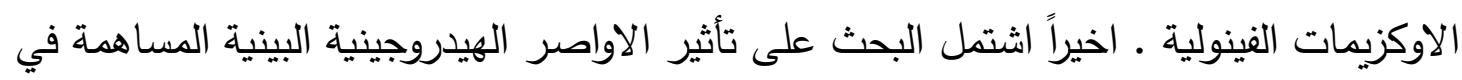
تكتل الايمينات و تم مناقشتها . 


\section{Introduction}

During the last few years imine as oxime form was prepared by novel ionic liquid water biphase system ${ }^{[1]}$ and in a green conditions ${ }^{[2]}$,other workers had prepared Schiff bases by the aid of microwave ${ }^{[3-4]}$ without using solvent. The wide applications of imines in different fields ,encourage the workers to increase experimentation in such direction as ,antimicrobial ${ }^{[5-6]}$ activity , biological ${ }^{[7]}$ study , biomarkers ${ }^{[8]}$, analytical ${ }^{[9]}$ study and metal complexation ${ }^{[10]}$. During the last decade Azzouz etal had interested in imines chemistry in a directions of thermodynamic ${ }^{[11]}$,kinetic ${ }^{[12]}$,tautomerism ${ }^{[13-14]}$, and pka ${ }^{[15]}$ studies .

The present work deals with synthesis of imines derived from different carbonyl compounds as 2-acetyl pyridine ,3 or 4 -hydroxy benzaldehyde and $\mathrm{m}$-anisaldehyde with aromatic primary amines. The structures of these imines were studies by the available physical methods namely ,UV-IR spectra and melting points or boiling point, some chemical testes were applied to confirm the structures of imines.

Association studies in these imines by the aid of hydrogen bonding and their influence on melting point was also discussed. The study included some ,tautomerism studies in oximes and phenolic oximes . Honestely, this synthetic work may open way to others studies dealing with pka for imines under study.

\section{Experimental}

All chemicals used in this study were of Fluka or BDH origin . Schiff bases and syn aldoximes were prepared by standard methods ${ }^{[16-17]}$. This was by mixing equivalent amounts of their aldehyde with an appropriate primary amine. The collected imines were purified by recrystallization from $50 \%$ ethanol_water by volume . Anti aldoximes were prepared by charcoal method ${ }^{[17]}$ in benzene solvent .

\section{Instrumentations}

1. The U.V. spectra of syn and anti aldoximes were measured by double beam computerized U.V. 1601 Shimadzu spectrophotometer, using two matched quartz cells of dimensions $1 \times 1 \times 3 \mathrm{~cm}$.

2. The IR spectra of solid and liquid aldoximes had measured by using a computerized FTIR Brucker Tensor 27 spectrophotometer.

3. The temperature of any solution was fixed by using Memmert Searl L200 water thermostat. 
4. The melting points of solids syn and anti oximes was measured by using Electrothermal melting point apparatus.

\section{Results and discussion}

Table(1) shows the compound number, nomenclature and structure of fifteen imines prepared.

\section{Methods used for identification of imines}

\section{1-specific chemical ${ }^{[18]}$ tests:}

Table(2) showed specific chemical tests were used in identification of imines under study .This included $\mathrm{FeCl}_{3}$ reagent used in identification of $\mathrm{OH}$ groups in oxime and phenolic forms . This gave positive tests for all imines numbered (1-12). Also the halogen test was applied to imines numbered (13-14) with positive results. Finally a positive ether test was applied to imines $(7,8,15)$. These three testes were in agreement with the structures of imines as in Table (2) .

Table (1) : Compound number, nomenclature and structures of imines

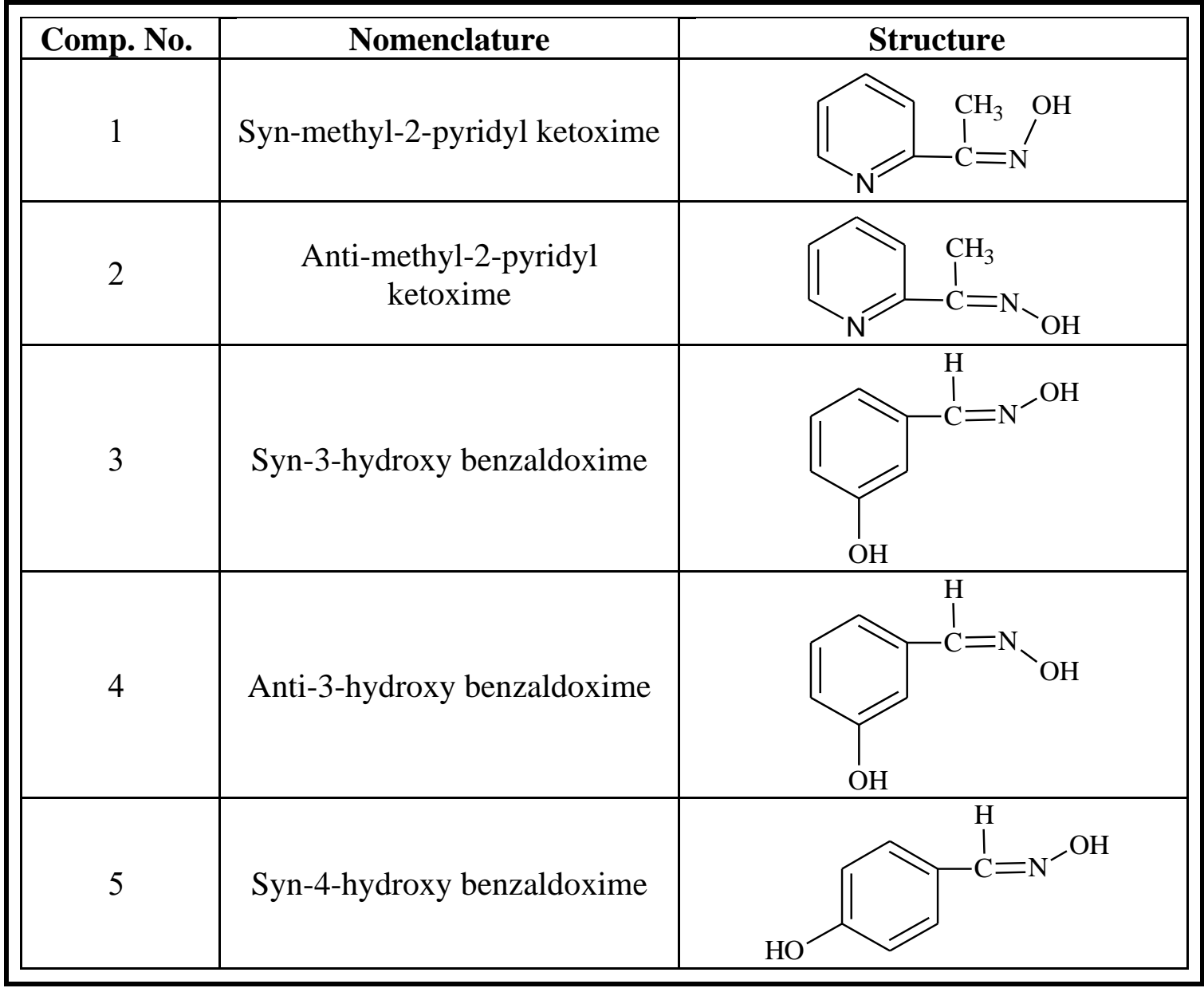


Physical and Chemical Methods Used for Determination of Structures of Some ...

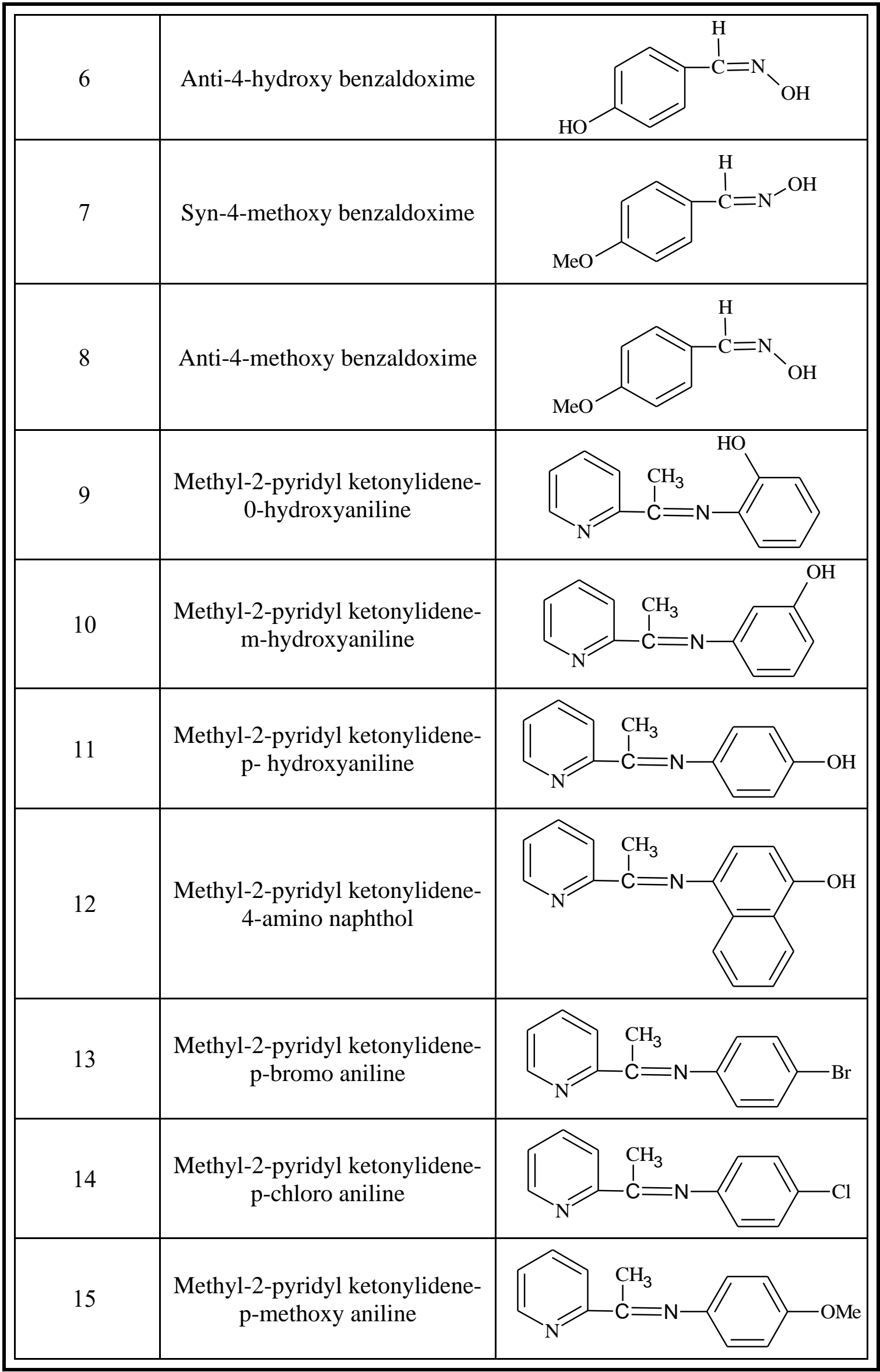


2- physical measurements :

These included the followings :

\subsection{Melting points}

As known in literature ${ }^{[19]}$, melting points of organic compounds were varied by their chemical structures, isomers and hydrogen bonds . A numbers of researchers ${ }^{[19]}$ observed previously that melting points of organic compounds varied with the degree of association, as happen for example by inter molecular hydrogen bond. This was the main reason of variation of melting points for oximes ${ }^{[17]}$ as an example, when were prepared by different methods . In order to clarify this point, the following divisions were essential :-

a- Oximes:

The melting points of oximes syn or anti as numbered (1-2), as observed in Table(2) that melting point of syn was greater than anti analogue. These were in agreement with oximes syn and anti numbered(5-8). A difficult comparison could be done on syn and anti oximes derived 3-hydroxy benzaldehyde. These were because the syn and anti isomers numbered 3 and 4 respectively, were in liquid and solid states respectively.

\section{b-Phenolic Schiff bases:}

The melting points of phenolic Schiff bases $(9,10,11)$ were in the following arrangement $(\mathrm{p}-\mathrm{OH}>\mathrm{O}-\mathrm{OH}>\mathrm{m}-\mathrm{OH})$ as in Table $(2)$.

These were expected due to the presence of inter, intra and intra molecular hydrogen bondings in these molecures respectively. This resulted to easier association (polymerization ) of $\mathrm{p}-\mathrm{OH}$, and hence a greater melting point was resulted.

On the contrary to that in intra molecular hydrogen bondings as in phenolic Schiff bases 9 and 10 was responsible of reducing ${ }^{[19]}$ the melting point. The lower melting point of phenolic Schiff base was due to its structure as explained above.

\section{2 boiling points}

This includes the halogenated imines numbered 13 and 14 as in Table(2). having boiling points $182 \mathrm{C}^{\circ}, 157 \mathrm{C}^{\circ} \circ$ respectively . Imines 13 contained p$\mathrm{Br}$ group of higher atomic weight in its structure, while imine 14 contained $\mathrm{p}-\mathrm{Cl}$ of relatively lower atomic weight .

As a result a higher molecular weight resulted to imine 13 . This result was in agreement with literature ${ }^{[19]}$. Imine 15 that contained $\mathrm{p}-\mathrm{OCH}_{3}$ group boils at $120 \mathrm{C}^{\circ}$, as agreed with lower relative boiling point of ether compounds. 
Physical and Chemical Methods Used for Determination of Structures of Some ...

Table(2) : Specific chemical testes with melting points or boiling points of oximes

\begin{tabular}{|c|c|c|c|c|}
\hline Comp. No. & $\mathrm{FeCl}_{3}$ test & Halogen test & Ether test & $\begin{array}{l}\text { melting points or } \\
\text { boiling points }\end{array}$ \\
\hline 1 & $+\mathrm{ve}$ & - & - & $120-119$ \\
\hline 2 & $+\mathrm{ve}$ & - & - & 114 \\
\hline 3 & $+\mathrm{ve}$ & - & - & $* 112$ \\
\hline 4 & $+\mathrm{ve}$ & - & - & 82 \\
\hline 5 & $+\mathrm{ve}$ & - & - & 62 \\
\hline 6 & $+\mathrm{ve}$ & - & - & 88 \\
\hline 7 & $+\mathrm{ve}$ & - & $+\mathrm{ve}$ & 86 \\
\hline 8 & $+\mathrm{ve}$ & - & $+\mathrm{ve}$ & $105-104$ \\
\hline 9 & $+\mathrm{ve}$ & - & - & 185 \\
\hline 10 & $+\mathrm{ve}$ & - & - & 168 \\
\hline 11 & $+v e$ & - & - & 209 \\
\hline 12 & $+\mathrm{ve}$ & - & - & 55 \\
\hline 13 & - & $+\mathrm{ve}$ & - & $* 182$ \\
\hline 14 & - & $+\mathrm{ve}$ & - & $* 157$ \\
\hline 15 & - & - & $+\mathrm{ve}$ & $* 120$ \\
\hline
\end{tabular}

* boiling points

\section{2-IR spectra}

The IR spectra of solid or liquid imines were measured . Results were collected as in Table (3) and showed the following :-

1- The appearance of medium to strong stretching vibration for $\mathrm{C}=\mathrm{N}$ at range of wave numbers (1611.41-1666.73) $\mathrm{cm}^{-1}$.

2-The stretching C-H group in imines numbers $(1,2,7,9,11-15)$ as medium to strong band of wave numbers range (3065.06-3013.07) $\mathrm{cm}^{-1}$.

3-The appearance of stretching aromatic (benzene or pyridine) band for all imines with variable intensities in the range of wave numbers (1536.891608.16) $\mathrm{cm}^{-1}$, with exclusion of imine number 10 . These last might be due interaction of aromatic ring with azomethine group .

4-The $\mathrm{OH}$ bands in imines numbers (1-12), showed a broad to medium intensities stretching bands of wave numbers range (3105.31-3368.33) $\mathrm{cm}^{-1}$.

5-The appearance of strong stretching vibration of $\mathrm{N}=\mathrm{O}$ group in oximes (18 ) at a range of wave numbers $(1509.94-1565.68) \mathrm{cm}^{-1}$. This was due to tautomerism of oxime group, as shown later in this manuscript .

6-The appearance of medium to strong stretching bands for N-O group in oximes numbered (1-8) at range of wave numbers $(935.57-1005.99) \mathrm{cm}^{-1}$. 
7- The appearance of medium to strong intensities stretching C-O band for imines numbered(1-12) at a range of wave numbers (1213.58-1236.95) $\mathrm{cm}^{-1}$.

8- The appearance of stretching $\mathrm{C}=\mathrm{O}$ bands of different intensities in imines (3-6), (9-12) at a range of wave numbers $(1687.5-1697.95) \mathrm{cm}^{-1}$. This was due to conversion of enol tautomer in imine mentioned to keto tautomer as seen later.

9- The appearance of strong stretching $\mathrm{C}-\mathrm{X}$ bands in imines numbered 13 and 14 at wave numbered $(623.43) \mathrm{cm}^{-1}$ and $(822.82) \mathrm{cm}^{-1}$ respectively . 10- The appearance of medium intensities stretching bands for $\mathrm{O}_{-} \mathrm{CH}_{3}$ ether group in imines 7 and 15 at wave numbered $(1180.04) \mathrm{cm}^{-1}$ and (1149.84) $\mathrm{cm}^{-1}$ respectively.

\section{Spectroscopic methods used for identification of hydrogen bond}

This methods was applied for the investigation of hydrogen bonding in imines (1-12), as follows :-

\section{Electronic spectra}

The Electronic spectra were used ${ }^{[19]}$ by many workers for the investigation of hydrogen bonding in organic compounds. The electronic spectra for oxime and phenolic imines were measured in polar ethanol solvent and in non polar benzene solvent typical example is shown in Fig. 1 for imine (3). The type of transitions $\pi \rightarrow \pi^{*}$ in imines were identified from values of molar extinction coefficients $\Sigma_{\max }$ as in Table (4). This showed $\Sigma_{\max }$ values of more than $1000 \mathrm{~L} . \mathrm{mol}^{-1} \cdot \mathrm{cm}^{-1}$, which identified $\pi \rightarrow \pi^{*}$ transitions, confirmed by negative $\Delta \mathrm{v}$ values from the following relationship :-

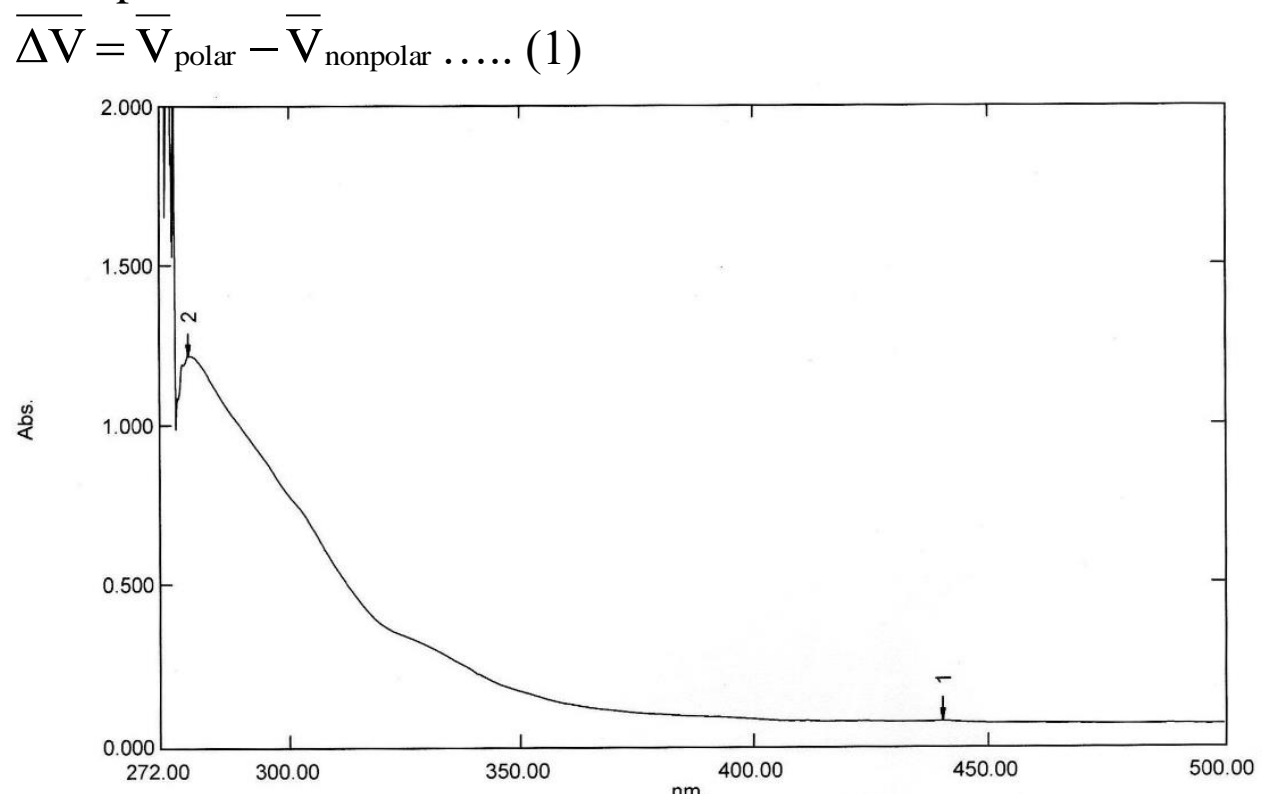

Fig. $1:\left(10^{-4}\right) \mathrm{M}$ UV spectrum for imine (3) in benzene

Results collected in Table (4) showed that imines(1-12)had hydrogen bonding ${ }^{[17,19,20]}$. 


\section{The I.R spectra}

In order to confirm the type of intra or inter molecular hydrogen bonding exist in imines (1-12), hence it was decided to use the dilution method ${ }^{[19,20]}$ to interpret the type of bonding . Accordingly $10^{-3} \mathrm{M}$ or $10^{-4} \mathrm{M}$ solutions for imines numbered (1-12) were prepared in benzene solvent . Spectra for imines were measured before and after dilution to ratios 1:3. Typical spectrum was shown in Fig. 2 for imines (1) . 


\section{Table (3) : Wave numbers for imines in solid state}

\begin{tabular}{|c|c|c|c|c|c|c|c|c|c|c|}
\hline $\begin{array}{l}\text { Comp } \\
\text {. No. }\end{array}$ & $v C=N$ & vC-H & vArom & vO-H & $\mathrm{vN}=\mathrm{O}$ & $\mathrm{vN}-\mathrm{O}$ & vC-O & $v C=0$ & $v C-X$ & vC-OCH3 \\
\hline 1 & $1652.65(\mathrm{~s})$ & $\begin{array}{c}3063.30(\mathrm{~m} \\
)\end{array}$ & 1591.66(s) & $3158.87(b)$ & $1565.68(\mathrm{~s})$ & $935.57(\mathrm{~s})$ & $1245.42(\mathrm{~s})$ & - & - & - \\
\hline 2 & $1628.62(\mathrm{~s})$ & $\begin{array}{c}3063.42(\mathrm{~m} \\
)\end{array}$ & $1591.78(\mathrm{~s})$ & $3160.89(\mathrm{~m})$ & $1541.75(\mathrm{~s})$ & 936.02(s) & $\begin{array}{c}1245.07(\mathrm{~m} \\
)\end{array}$ & - & - & - \\
\hline 3 & $\begin{array}{c}1656.25(\mathrm{~m} \\
)\end{array}$ & - & $1582.44(\mathrm{~s})$ & $\begin{array}{c}3226.29(\mathrm{vb} \\
)\end{array}$ & $\begin{array}{c}1538.87(\mathrm{~m} \\
)\end{array}$ & 937.03(m) & $\begin{array}{c}1233.41(\mathrm{~m} \\
)\end{array}$ & 1687.5(w) & - & - \\
\hline 5 & $\begin{array}{c}1636.66(\mathrm{~m} \\
)\end{array}$ & - & $\begin{array}{c}1608.16(\mathrm{~m} \\
)\end{array}$ & $\begin{array}{c}3105.31(\mathrm{vb} \\
)\end{array}$ & $1539.65(\mathrm{~s})$ & $\begin{array}{c}1005.99(\mathrm{~m} \\
)\end{array}$ & $1228.12(\mathrm{~s})$ & $\begin{array}{c}1792.45(\mathrm{vw} \\
)\end{array}$ & - & - \\
\hline 6 & 1611.51(s) & - & $1586.66(\mathrm{~s})$ & $3288.57(b)$ & $1509.94(\mathrm{~s})$ & $\begin{array}{c}1005.18(\mathrm{~m} \\
)\end{array}$ & $1223.44(\mathrm{~s})$ & 1734.9(s) & - & - \\
\hline 7 & $1611.41(\mathrm{~s})$ & $\begin{array}{c}3065.06(\mathrm{~m} \\
)\end{array}$ & $1536.89(\mathrm{~s})$ & $3123.09(\mathrm{~m})$ & $1519.87(\mathrm{~s})$ & $947.67(\mathrm{~s})$ & $1214.22(\mathrm{~s})$ & - & - & $\begin{array}{c}1180.04(\mathrm{~m} \\
)\end{array}$ \\
\hline 9 & $\begin{array}{c}1666.73(\mathrm{~m} \\
)\end{array}$ & $\begin{array}{c}3015.18(\mathrm{~m} \\
)\end{array}$ & 1588.4(vs) & $3305.18(\mathrm{~m})$ & - & - & $1216.25(\mathrm{~s})$ & 1697.87(s) & - & - \\
\hline 10 & $\begin{array}{c}1614.45(\mathrm{~m} \\
)\end{array}$ & - & - & 3363.99(b) & - & - & $\begin{array}{c}1239.81(\mathrm{~m} \\
)\end{array}$ & $1694.87(\mathrm{~s})$ & - & - \\
\hline 11 & $\begin{array}{c}1636.22(\mathrm{~m} \\
)\end{array}$ & $\begin{array}{c}3059.33(\mathrm{w} \\
)\end{array}$ & $1586.81(\mathrm{~s})$ & $3221.57(b)$ & - & - & $1237.78(\mathrm{~s})$ & $1697.95(\mathrm{vs})$ & - & - \\
\hline 12 & $1623.07(\mathrm{~s})$ & $3013.17(\mathrm{~s})$ & $1575.21(\mathrm{~s})$ & $3368.15(\mathrm{~m})$ & - & - & $1263.95(\mathrm{~s})$ & $1694.89(\mathrm{~s})$ & - & - \\
\hline 13 & $1623.25(\mathrm{~s})$ & $3055.8(\mathrm{~m})$ & $1594.03(\mathrm{~s})$ & - & - & - & - & - & $\begin{array}{c}623.43(\mathrm{~s} \\
)\end{array}$ & - \\
\hline 14 & $1624.28(\mathrm{~s})$ & $\begin{array}{c}3055.06(\mathrm{~m} \\
)\end{array}$ & 1584.44(s) & - & - & - & - & - & $\begin{array}{c}822.82(\mathrm{~s} \\
)\end{array}$ & - \\
\hline 15 & $1635.05(\mathrm{~s})$ & $\begin{array}{c}3045.23(\mathrm{~m} \\
)\end{array}$ & $1584.30(\mathrm{~s})$ & - & - & - & $1213.58(\mathrm{~s})$ & - & - & $1149.84(\mathrm{~m})$ \\
\hline
\end{tabular}


$\mathrm{M}=$ medium , $\quad \mathrm{w}=$ weak,$\quad \mathrm{vb}=\mathrm{very}$ broad, $\quad \mathrm{s}=$ sharp

Table (4) : Identification of hydrogen bondings by UV spectra for imines (1-12) in ethanol and benzene solvents at concentration range $\left(10^{-6}-10^{-4}\right) \mathrm{M}$

\begin{tabular}{|c|c|c|c|c|c|c|c|c|}
\hline \multirow[b]{2}{*}{ Comp. No. } & \multicolumn{3}{|c|}{ Ethanol Solvent } & \multicolumn{3}{|c|}{ Benzene Solvent } & \multirow{2}{*}{$\begin{array}{l}\text { Type of } \\
\text { transition }\end{array}$} & \multirow{2}{*}{$\begin{array}{c}\overline{\Delta V} \\
\mathbf{c m}^{-1}\end{array}$} \\
\hline & $\lambda_{\max }(\mathrm{nm})$ & $\begin{array}{c}\bar{V} \text { ethanol } \\
\left(\mathbf{c m}^{-1}\right)\end{array}$ & 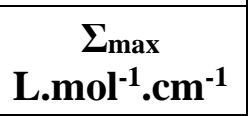 & $\lambda_{\max }(\mathrm{nm})$ & $\begin{array}{c}\bar{V} \text { benzene } \\
\left(\mathrm{cm}^{-1}\right)\end{array}$ & $\begin{array}{c}\Sigma_{\max } \\
\text { L.mol }{ }^{-1} \cdot \mathbf{c m}^{-1} \\
\end{array}$ & & \\
\hline 1 & 270.5 & $3.69 \times 10^{4}$ & 2610 & 268.6 & $3.72 \times 10^{4}$ & 16140 & $\pi \rightarrow \pi^{*}$ & -300 \\
\hline 2 & 271.5 & $3.68 \times 10^{4}$ & 4340 & 267.4 & $3.74 \times 10^{4}$ & 20590 & $\pi \rightarrow \pi^{*}$ & -600 \\
\hline 3 & 299.6 & $3.34 \times 10^{4}$ & 6310 & 278.2 & $3.59 \times 10^{4}$ & 12220 & $\pi \rightarrow \pi^{*}$ & -2500 \\
\hline 4 & 294.8 & $3.39 \times 10^{4}$ & 10680 & 289.2 & $3.46 \times 10^{4}$ & 5710 & $\pi \rightarrow \pi^{*}$ & -700 \\
\hline 5 & 249.8 & $4 \times 10^{4}$ & 95700 & 246.8 & $4.05 \times 10^{4}$ & 21720 & $\pi \rightarrow \pi^{*}$ & -500 \\
\hline 6 & 248.6 & $4.02 \times 10^{4}$ & 99600 & 239.6 & $4.17 \times 10^{4}$ & 19920 & $\pi \rightarrow \pi^{*}$ & -1500 \\
\hline 7 & 249.0 & $4.02 \times 10^{4}$ & 80700 & 238.6 & $4.19 \times 10^{4}$ & 19810 & $\pi \rightarrow \pi^{*}$ & -1700 \\
\hline 8 & 248.2 & $4.03 \times 10^{4}$ & 115400 & 247 & $4.05 \times 10^{4}$ & 17490 & $\pi \rightarrow \pi^{*}$ & -200 \\
\hline 9 & 215.5 & $4.64 \times 10^{4}$ & 25340 & 214.6 & $4.66 \times 10^{4}$ & 11340 & $\pi \rightarrow \pi^{*}$ & -200 \\
\hline 10 & 214.5 & $4.66 \times 10^{4}$ & 26150 & 202.8 & $4.93 \times 10^{4}$ & 21010 & $\pi \rightarrow \pi^{*}$ & -2700 \\
\hline 11 & 296.5 & $3.71 \times 10^{4}$ & 4470 & 269.2 & $4.714 \times 10^{4}$ & 19000 & $\pi \rightarrow \pi^{*}$ & -40 \\
\hline 12 & 317.2 & $3.15 \times 10^{4}$ & 19450 & 316.2 & $3.16 \times 10^{4}$ & 331100 & $\pi \rightarrow \pi^{*}$ & -100 \\
\hline
\end{tabular}


Physical and Chemical Methods Used for Determination of Structures of Some ...

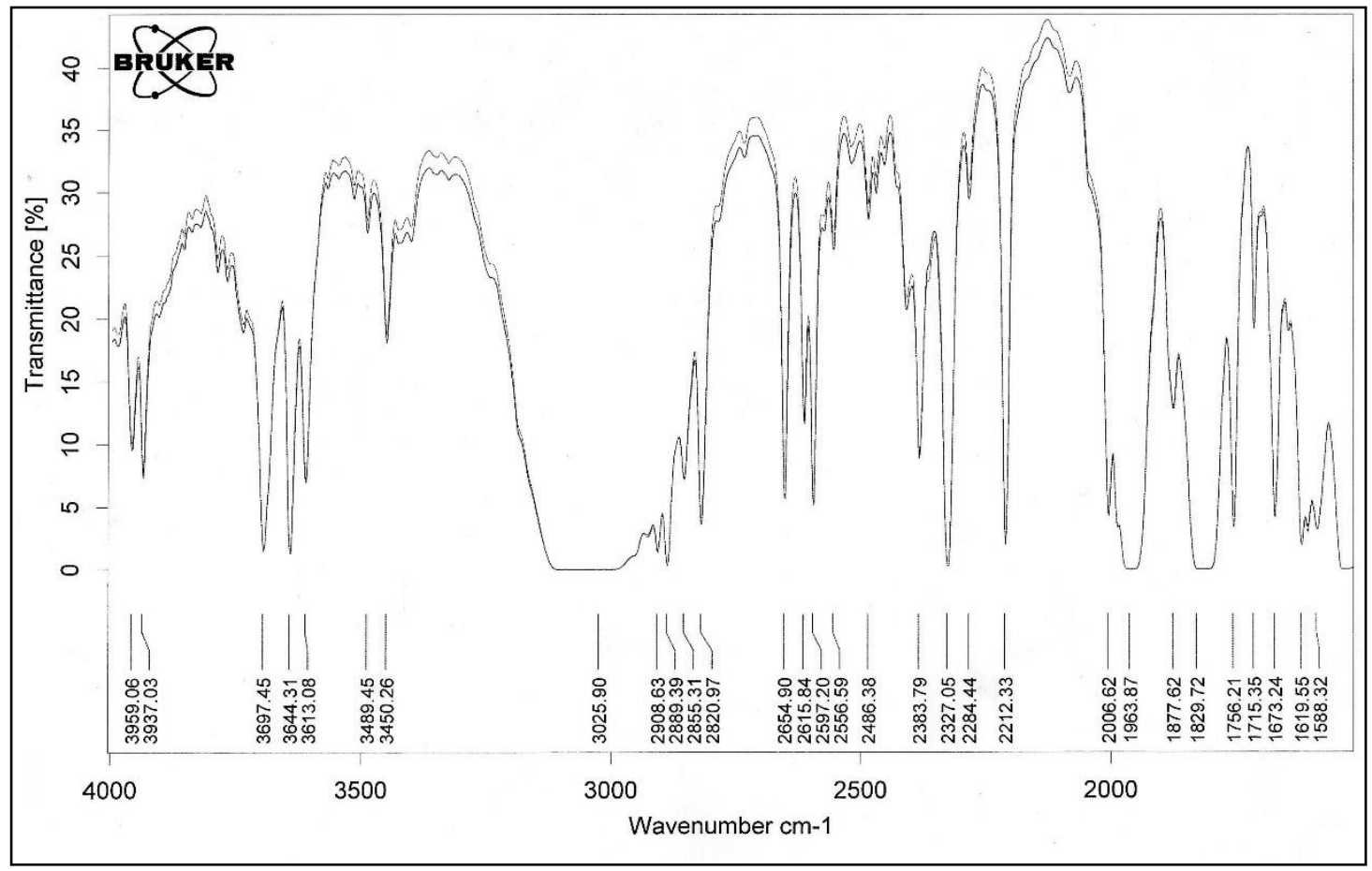

Fig. 2: IR spectra of imine 2 before and after dilution to ratio 1:3

Results collected from these measurement for imines (1-12) was shown in Table (5)

Table (5): Types of hydrogen bonds (H.B) in imines numbered (1-12) in benzene solvent using (IR) technique

\begin{tabular}{|c|c|c|}
\hline Comp. No. & $\begin{array}{c}\text { Wave number of H.B } \\
\left(\mathrm{cm}^{-1}\right)\end{array}$ & Type of H.B \\
\hline 1 & 3450.32 & inter \\
\hline 2 & 3450.26 & intra \\
\hline 3 & 3450.23 & inter \\
\hline 4 & 3450.21 & inter \\
\hline 5 & 3450.22 & inter \\
\hline 6 & 3450.21 & inter \\
\hline 7 & 3450.22 & inter \\
\hline 8 & 3450.25 & inter \\
\hline 9 & 3450.21 & intra \\
\hline 10 & 3450.22 & intra \\
\hline 11 & 3450.17 & inter \\
\hline 12 & 3450.17 & inter \\
\hline
\end{tabular}

Table (5) showed imines numbered (2,9)and (10) contained only intra molecular hydrogen bonding. The rest had inter molecular hydrogen bondings . 


\section{Tautomerism study in oxime and phenolic oximes}

It was appeared in Table (3) two stretching I,R vibrations, the first one related to $\mathrm{N}=\mathrm{O}$ at a range of wave number $(1519.87-1565.68) \mathrm{cm}^{-1}$. The second related to $\mathrm{C}=\mathrm{O}$ vibrations at range of wave number (1687.5$1792.45) \mathrm{cm}^{-1}$. These two bands could be accepted by following reactions mechanism :-

1-Tautomerism of oximes, Typical example was chosen as in imines(1), resulted to the formation of nitroso form as in scheme (1) .<smiles>CC(C)(c1ccccn1)N1CCO1</smiles>

Enol form<smiles>CC(N=O)c1ccccn1</smiles>

nitroso form

Schem(1): Tautomerism of imines (1)

This tautomerism reaction was in agreement with $(1,3)$ shift observed in literature ${ }^{[21]}$.

2-Tautomerism of phenolic oxime as in imine (3). This contained phenol and oxime groups together in the same imine. This type of tautomerism was illustrated in Scheme (2), resulted of conversion ${ }^{[22]}$ of phenol group to carbonyl group.<smiles>COc1cccc(/C=N/O)c1</smiles><smiles>C=C=C</smiles>

$\operatorname{Schem}(2)$ : (1,3)-Tautomerism reaction in imine (3)

\section{Conclusions}

1- The structures of imines in a forms syn or anti oximes and Schiff bases were confirmed by physical method, namely m.p 's , UV and IR spectra, beside chemical method. The last included specific reagents for phenol, ether linkages and halogen test.

2- In solid state, oximes numbered (1-2) under go a strong tautomerism process $^{(21)}$ of type enol-nitroso form, where as phenoic oxime number (3) showed weak tautomerism process ${ }^{(22)}$ of type enol-keto form. 
3- A strong inter hydrogen bonding in an imine under study, lead to higher melting or boiling point as a result of higher polymerization ${ }^{(19)}$ or association process.

\section{References}

1- Luo H.M. , Li V. LP. and Zheng W. J., Chinese Chemical letters , 16(7), 906(2005).

2- Gharib A. , Jahangir M. and Roshani M. , $12^{\text {th }}$ ed. International Electronic Conference on Synthetic Organic Chemistry (ECSOC-12),(2008).

3- Yarg H.J. , San W. H. , Li Z. L. and Ma Z. , Chinese Chem . Letters . 13(1) ,3-6(2002).

4- Kulshrestha A. and Baluja S., Scholars Research Library , , 2(3),221(2010).

5- Raman N., Raja J.D. and Sakthival A. ,J. Chem. Sci .,119.303(2007) .

6- Aureus S., Coli E., Albicans S. C. , Rhizopussp and A. Niger, Organic Chemistry Intern . Article , ID $648589,7(2010)$.

7- Ghosh S. , Malik S. , Jain B. and Ganesh N. , Asian J.Exp.Sci , ,23(1) 189(2009).

8- Korytar P. , Molnorova M. , Sivonova M. , Zitnanova I. O. Ulicna and Liptakova A. , Corsky T. and Durackova Z., Gen . physiol .Biophys ., 21, 337(2002).

9- Katyal M. and Dutt Y., Talanta, , 22, 51(1975).

10- Goel S., Lat K., Asian J. Chem ., 2, 271(1990).

11- Azzouz A.S.P. , Z.Phys. Chem ., 216, 1(2002).

12- A.S.P. and B.D. Kashmola, Phy. Chem .An Indian J.,2011, 6(2), 1.

13- Azzouz A.S.P., Ahmed S.A. and AL-Hyali R.H., , Nat .J.Chem ., 39, 499(2010).

14- Azzouz A.S.P. and AL-Dabagh A.B.N., Nat .J.Chem , 26, 295(2007).

15- Azzouz A.S.P. and AL-Bakzo D.P., Phy. Chem An Indian J , 7(1), 2(2012).

16- Vogel A.F., Textbook of Practical Organic Chemistry , 4 th ed. Longman , London, 847(1978).

17- Majer J.R. and Azzouz A.S.P., J.Chem. Soc . Farad. Trans. 1, 79, 675(1983).

18- Cheronis N.D. and Entrikin J.B., Identification of Organic Compounds, John Wiley and Sons, New York, 132-147(1983).

19- Pimental G.C. and Mecellellan A.L., The Hydrogen Bond, Freeman ,San Franceisco, New York, 129-195(1960).

20- Azzous A.S.P., Rahman A.A.A. and Taki A.G., J.Edu. Sci . 15, 1(2003).

21- March J., Advanced Organic Chemistry , McGraw Hill , London , 7677(1973).

22- Zabicky Ed.J., The Chemistry of Carbonyl Group, vol.2, Interscience , London, 157-239(1970). 